\title{
Penilaian Kualitas Airtanah untuk Air Minum dan Air Irigasi di Kota Banjarbaru dan Sekitarnya
}

\author{
Firza Syarifa Zahra $^{1 *}$ Thomas Triadi Putranto ${ }^{1,2}$, Fuad Muhammad ${ }^{1,3}$ \\ ${ }^{1}$ Sekolah Pascasarjana Ilmu Lingkungan, Universitas Diponegoro, Indonesia \\ ${ }^{2}$ Program Studi Teknik Geologi, Universitas Diponegoro, Indonesia \\ ${ }^{3}$ Program Studi Biologi, Universitas Diponegoro, Indonesia
}

\begin{abstract}
Abstrak
Airtanah merupakan salah satu sumber air bersih bagi masyarakat Kota Banjarbaru dan sekitarnya. Jumlah air bersih yang semakin terbatas dan kualitas airtanah yang semakin buruk menjadi isu yang mengkhawatirkan saat ini. Penelitian ini bertujuan untuk mengetahui kualitas airtanah untuk air minum dan air irigasi bagi masyarakat kota banjarbaru dan sekitarnya. Dalam penelitian ini diambil 10 sampel airtanah untuk mengetahui sifat fisik dan sifat kimia airtanah. Penilaian kualitas airtanah untuk air minum menggunakan WQI, sedangkan penilaian kualitas airtanah untuk air irigasi menggunakan SAR, Na\%, dan RSC. Hasil analisis WQI menunjukkan terdapat $60 \%$ airtanah dengan kualitas sangat baik yang masih dapat dimanfaatkan sebagai air minum dan $40 \%$ kualitas buruk hingga tidak layak minum. Hasil SAR menunjukkan airtanah di lokasi penelitian sangat baik untuk irigasi. Analisis $\mathrm{Na} \%$ menunjukkan bahwa 20\% airtanah sangat baik untuk irigasi, 20\% baik untuk irigasi, $40 \%$ diperbolehkan untuk keperluan irigasi, dan sisanya $20 \%$ meragukan untuk air irigasi. Analisis RSC menunjukkan bahwa 90\% airtanah baik untuk air irigasi, dan $10 \%$ sisanya tidak cocok untuk air irigasi. Secara umum, airtanah untuk keperluan irigasi sekitar $80 \%$ dapat dimanfaatkan, sedangkan $20 \%$ sisanya tidak cocok untuk irigasi atau hanya dapat digunakan untuk tanaman-tanaman tertentu yang memiliki sifat tolerah terhadap kandungan garam yang tinggi. Pemanfaatan airtanah harus tepat sesuai dengan kualitasnya agar memperoleh manfaat yang maksimal dan tidak menimbulkan bahaya baik bagi kesehatan manusia mapun bagi pertanian.
\end{abstract}

Kata kunci: air minum; air irigasi; kualitas airtanah; Na\%; WQI; SAR; RSC

\begin{abstract}
Groundwater is a source of clean water for the people of Banjarbaru City and its surroundings. The amount of fresh water decreased and the worsening quality of groundwater is a worrying current issue. This study aims to see the quality of groundwater for drinking water and irrigation water for the community of Banjarbaru city and its surroundings. In this study, 10 samples of groundwater were taken to test the physical and chemical properties of groundwater. Groundwater quality drinking water uses the WQI, the provision of groundwater quality for irrigation water uses $S A R, N a \%$, and RSC. The results of the analysis using WQI show thatthere are $60 \%$ groundwater with very good quality that can still be used as drinking water and $40 \%$ is of poor quality so it is not suitable for drinking. Meanwhile, for irrigation purposes usingSAR, groundwater at the research location is very good for irrigation. Analysis using Na\% showsthat $20 \%$ have very good quality for irrigation, $20 \%$ have good quality for irrigation, $40 \%$ havepermissible quality for irrigation purposes, and the remaining $20 \%$ have dubious quality forirrigation water. Analysis using RSC shows that $90 \%$ are of good quality for irrigation water, andthe remaining $10 \%$ have unsuitable quality for irrigation water. In general, groundwater forirrigation purposes, about $80 \%$ can be utilized, while the remaining $20 \%$ is not suitable forirrigation or can only be used for certain plants which have high salt content characteristics. Utilization of groundwater must be appropriate in accordance with its quality in order toachieve maximum benefits and not cause harm to both human health and agriculture.
\end{abstract}

Keywords: drinking water; irrigation water; groundwater quality, Na\%; WQI; SAR; RSC

\footnotetext{
*) Korespondensi: firzasyarifa@gmail.com

Diajukan : 22 Maret 2021

Diterima : 17 Mei 2021

Diterbitkan : 31 Juli 2021
} 


\section{PENDAHULUAN}

Air merupakan salah satu unsur penting dalam kehidupan. Bagi manusia, air merupakan kebutuhan penting yang harus terpenuhi baik jumlah maupun kualitasnya. Saat ini sumber air yang banyak dimanfaatkan berasal dari airtanah. Akan tetapi, dewasa ini, ketersediaan akan airtanah yang bersih semakin terbatas. Hal ini dapat disebabkan oleh faktor alam maupun faktor antropogenik. Sehingga analisis kualitas airtanah merupakan kegiatan yang sangat penting dilakukan untuk mengetahui kondisi airtanah yang dapat digunakan untuk menunjang kehidupan manusia.

Kualitas airtanah tergantung pada berbagai faktor, seperti kondisi geologi, litologi, sifat akuifer, jenis tanah dan lain-lain (Jahanshahi dan Zare, 2016). Perubahan kualitas airtanah dapat dipengaruhi oleh interaksi antara air dan batuan atau adanya pengaruh aktivitas manusia (Sadashivaiah dkk., 2008). Aktivitas manusia seperti kagiatan industri, kegiatan rumah tangga yang menghasilkan limbah domestik dan aktivitas pertanian dapat mempengaruhi kualitas airtanah (Papaioannou dkk., 2006). Penilaian kualitas airtanah digunakan untuk mengetahui perubahan kualitas akibat interaksi antara air dan batuan atau pengaruh akitivitas manusia (antropogenik) (Sadashivaiah dkk., 2008).

Kualias airtanah dapat ditentukan dari $\mathrm{pH}$ dan konduktivitas (EC) (Putranto dkk., 2016). Penelitian ini menambahkan parameter jumlah zat terlarut (TDS) dan kesadahan. Nilai $\mathrm{pH}$ merupakan banyaknya unsur $\mathrm{H}^{+}$dan $\mathrm{OH}^{-}$baik yang berasal dari kontaminan maupun dari zat terlarut. Semakin banyak unsur $\mathrm{H}^{+}$maka nilai $\mathrm{pH}$ semakin rendah dan air bersifat asam. Apabila air banyak mengandung unsure $\mathrm{OH}^{-}$ maka nilai $\mathrm{pH}$ semakin tinggi dan air bersifat basa. Konduktivitas (EC) merupakan kemampuan air untuk menghantar listrik. Kandungan garam terlarut dalam air akan mempengaruhi nilai konduktivitas. Semakin banyak garam yang terlarut, maka semakin tinggi nilai daya hantar listriknya (Suharyadi, 1984). Jumlah zat terlarut merupakan jumlah konsentrasi zat yang terlarut dalam air (Suharyadi, 1984). Kesadahan disebabkan oleh kandungan $\mathrm{Ca}$ dan $\mathrm{Mg}$. ion-ion tersebut mudah terendapkan dapat bereaksi dengan air sabun. Dua tipe umum kesadahan adalah kesadahan karbonat yang berhubungan dengan $\mathrm{HCO}^{-}$dan $\mathrm{CO}_{3}{ }^{-}$serta kesadahan non karbonat yang

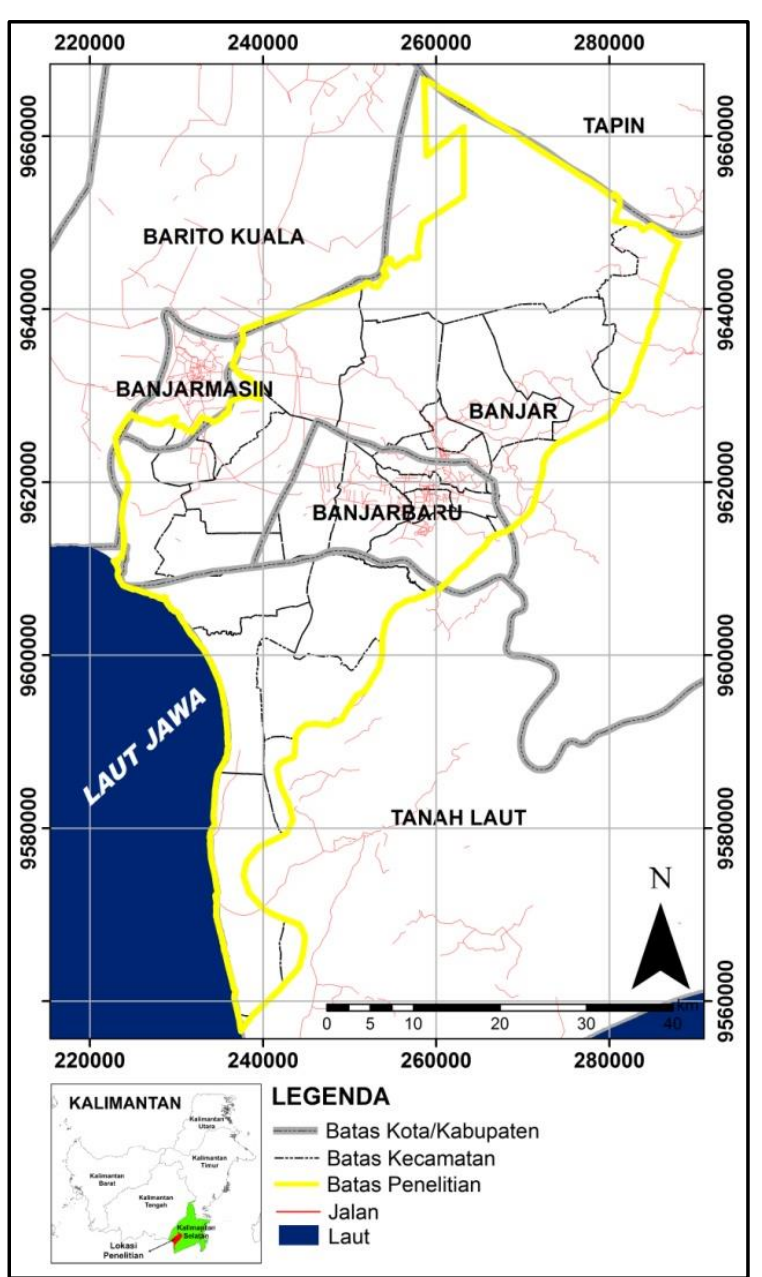

Gambar 1. Lokasi penelitian berada di Kota Banjarbaru dan sekitarnya. (Sumber: BIG, Sistem Referensi Geospasial Indonesia 2013)

berkaitan dengan $\mathrm{Cl}-$ dan $\mathrm{SO}_{4}{ }^{2-}$ (Supihatin dan Suparno, 2013).

Wilayah penelitian berada di Kota Banjarbaru dan sekitarnya (Gambar 1) yang secara geografis terletak di antara 222699 $288067 \mathrm{~m}$ (Timur) $/ 3^{0} 0$ ' 48" - $4^{0} 0$ ' $36^{\prime \prime}$ dan 9666610 - $9556512 \mathrm{~m}$ (Utara)/1140 30' 19” $115^{\circ} 05^{\prime} 28^{\prime}$. Berdasarkan BPS (Badan Pusat Statistik) Tahun 2015 dan Tahun 2018 tercatat peningkatan jumlah penduduk mencapai 20.923 jiwa dalam kurun waktu 4 tahun. Seiring bertambahnya jumlah penduduk tiap tahun, maka kebutuhan akan airtanah juga semakin meningkat. Mengingat hal tersebut, perlu adanya penilaian mengenai kualitas airtanah sehingga pemanfaatan airtanah dapat dilakukan dengan tepat. 
Masyarakat di wilayah Kota Banjarbaru dan sekitarnya umumnya memanfaatkan airtanah dangkal untuk memenuhi kebutuhan sehari-hari. Menurut Baalousha (2016), airtanah dangkal berpotensi untuk tercemar, hal ini disebabkan oleh kondisi hidrogeologi yang mempengaruhi masuknya kontaminan terlarut ke dalam airtanah. Menurut Abdullah (2018), air sumur di Kota Banjarbaru mengalami pencemaran akibat kedalaman sumur yang relatif dangkal dan jarak septic tank yang relatif dekat.

Penelitian ini bertujuan untuk mengetahui kondisi kualitas airtanah di Kota Banjarbaru dan sekitarnya. Penilaian kualitas airtanah didasarkan pada peruntukannya. Dalam penelitian ini penilaian kualitas airtanah untuk air minum berdasarkan parameter indeks kualitas air tanah yang diterbitkan oleh Organisasi Kesehatan Dunia (WHO) pada tahun 2011 sebagai standar baku mutu air untuk layak minum berskala internasional dan Peraturan Menteri Kesehatan (Permenkes) No.492/MENKES/PER/IV/2010 sebagai standar baku mutu air untuk layak minum berskala nasional.

\section{Kondisi Geologi Regional dan Hidrogeologi Regional}

Kondisi geomorfologi lokasi penelitian terbagi menjadi 5 kelompok, yaitu; satuan morfologi berbukit tersayat tajam, satuan morfologi berbukit bergelombang, satuan morfologi bergelombang, satuan morfologi bergelombang landai, dan satuan morfologi dataran.

Satuan morfologi tersayat tajam memiliki nilai persen kelerengan antara $21-55 \%$ dengan persebaran hanya $0,03 \%$ dari luas lokasi penelitian. Satuan morfologi berbukit bergelombang memiliki nilai persen kelerengan antara $14-20 \%$ dengan persebaran $0,11 \%$ dari luas lokasi penelitian. Satuan morfologi bergelombang memiliki nilai persen kelerengan antara $8-13 \%$ dengan persebaran $0,63 \%$ dari luas lokasi penelitian. Satuan morfologi bergelombang landai memiliki nilai persen kelerengan antara $3-7 \%$ dengan persebaran wilayah $7,2 \%$ dari lokasi penelitian. Satuan morfologi dataran memiliki nilai persen kelerengan antara 0-2\%. Lokasi penelitian didominasi satuan morfologi dataran dengan persebaran mencapai $92 \%$ dari luas lokasi penelitian.

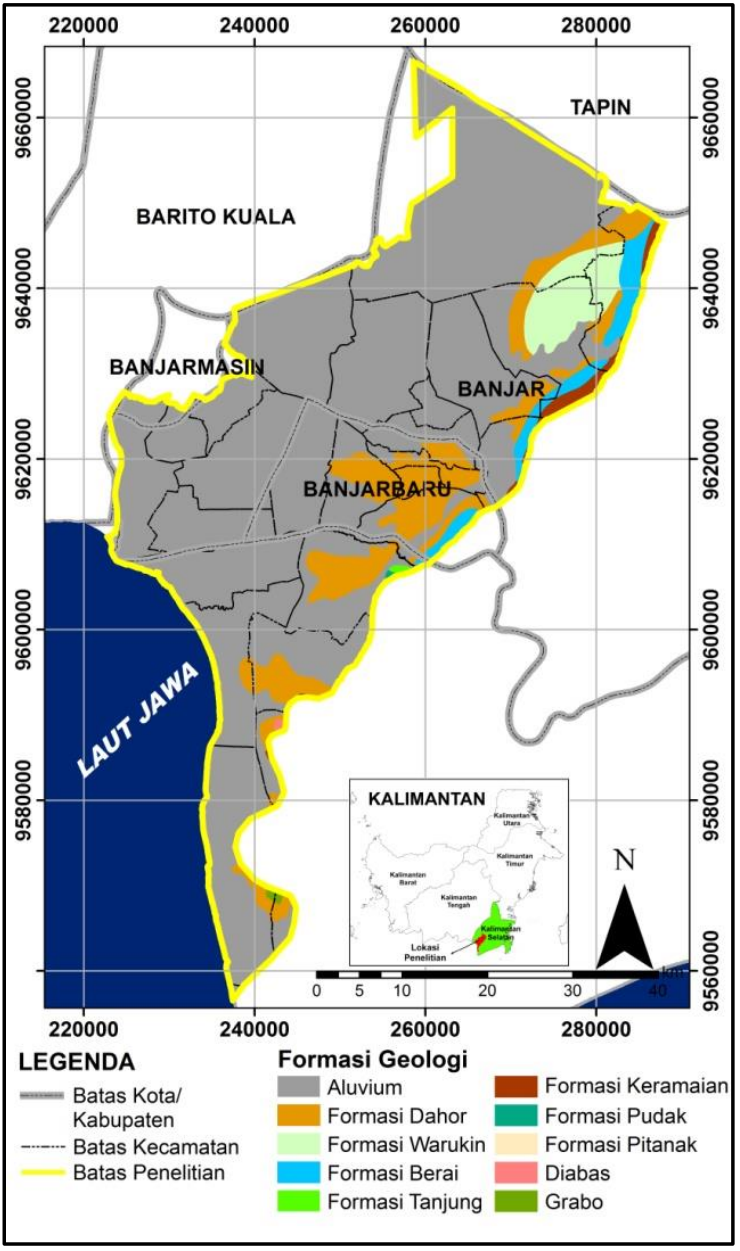

Gambar 2. Peta geologi regional lokasi penelitian (Sumber: BIG, Sistem Referensi Geospasial Indonesia 2013)

Berdasarkan peta geologi regional lembar Banjarmasin skala 1:250.000 (Heryanto dan Sikumbang, 1994), dapat diketahui bahwa kondisi geologi pada wilayah kerja memiliki berbagai jenis batuan pembentuk yang dapat dikelompokkan menjadi beberapa satuan batuan dan dapat diurutkan berdasarkan umur.

Berikut ini urutan satuan batuan dari yang berumur tua sampai muda yaitu; Gabro Kapur Awal (Mgb) yang berada pada bagian selatan lokasi penelitian dengan sebaran sebesar $0,10 \%$, Diabas yang berada pada bagian selatan lokasi penelitian dengan sebaran sebesar 0,05\%, Formasi Pudak (Kap) yang penyebarannya di bagian tengah timur lokasi penyelidikan dengan prosentase penyebaran 0,05\%, Formasi Pitanak (Kvpi) berada pada bagian tengah timur lokasi penyelidikan dengan prosentase penyebaran 0,04\%, Formasi Keramaian (Kak) berada pada bagian tengah barat dan setempat di selatan lokasi penelitian dengan sebaran sebesar $0,23 \%$, 
Formasi Tanjung (Tet) memiliki penyebaran di bagian Timur Laut dengan prosentase penyebaran 1,17\%, Formasi Berai (Tomb) berada di tengah menuju utara-timur laut lokasi penelitian dengan sebaran 2,42\%, Formasi Warukin (Tmw) berada setempat di bagian timur laut lokasi penelitian dengan penyebaran sebesar 3,55\%, Formasi Dahor (TQd) memiliki penyebaran dengan prosentase penyebaran sebesar $11,52 \%$ ditemukan pada bagian selatan, tengah hingga ke arah timur laut lokasi penelitian, dan Endapan Aluvium (Qa) yang paling dominan pada lokasi penelitian dengan penyebaran sebesar 80,88\% (Gambar 2).

Berdasarkan Peta Hidrogeologi Lembar Banjarmasin (Hidayat, 2001), lokasi penelitian memiliki kondisi hidrogeologi yang dapat dibedakan berdasarkan tipe aliran, yaitu: akuifer dengan aliran melalui ruang antar butir, akuiferdengan aliran melalui celahan, rekahan dan saluran pelarutan, dan akuifer bercelah atau

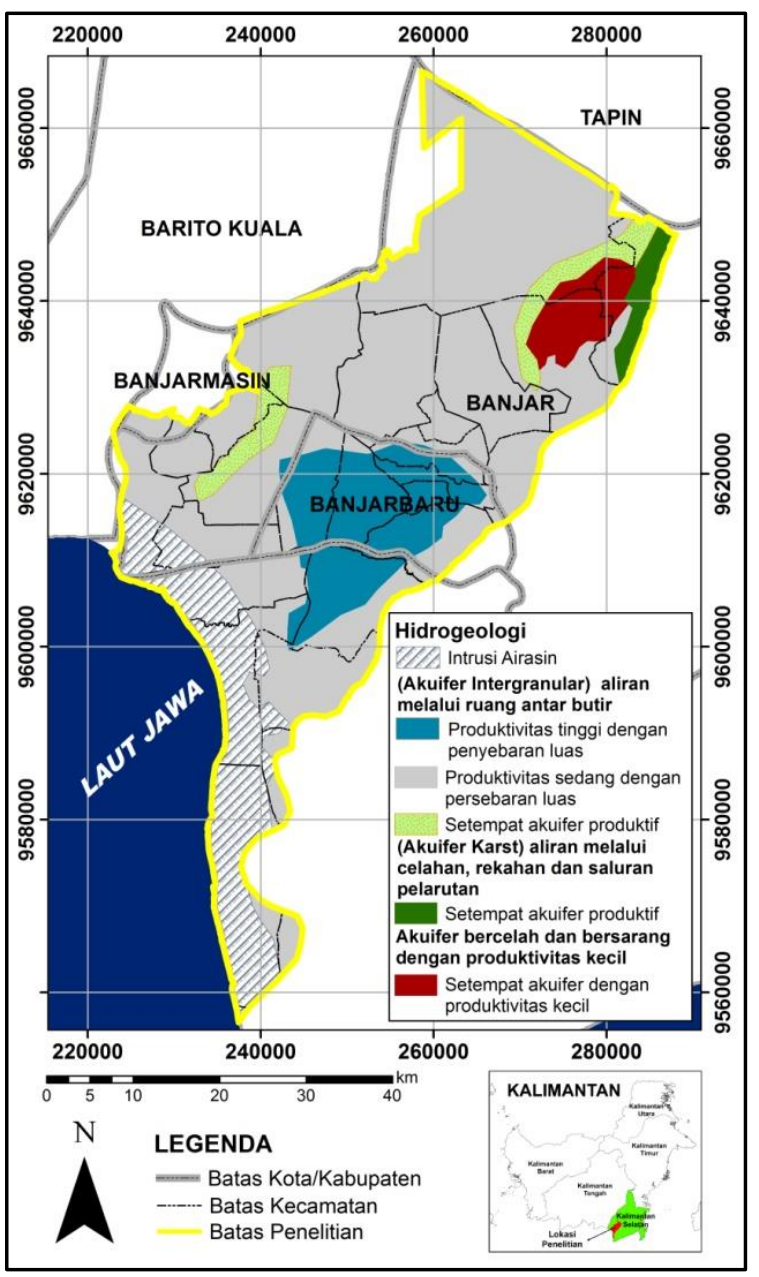

Gambar 3. Peta hidrogeologi regional lokasi penelitian bersarang (Gambar 3).

\section{METODOLOGI}

Metode yang digunakan dalam penelitian ini terbagi menjadi 3 , yaitu metode pengambilan dan analisis data, metode penilaian kualitas airtanah, dan metode analisis spasial.

Metode pengambilan data dilakukan dengan pemetaan hidrogeologi. Kegiatan pemetaan hidrogeologi berupa pengukuran muka airtanah (MAT) dan pengambilan sampel airtanah. Pengambilan sampel didasarkan pada jenis litologi dan tataguna lahan. Sebanyak 150 sampel airtanah diuji menggunakan alat WTW untuk mengetahui sifat fisika airtanah. Parameter yang diuji yaitu $\mathrm{pH}$, kondutivitas (EC), dan jumlah zat terlarut (TDS). Sebanyak 10 sampel airtanah diuji di laboratorium untuk mengatahui kandungan kimia berupa $\mathrm{Cl}^{-}, \mathrm{HCO}_{3}{ }^{-}$, $\mathrm{SO}_{4}{ }^{2-}, \mathrm{Ca}^{2+}, \mathrm{Mg}^{2+}, \mathrm{Na}^{+}, \mathrm{K}^{+}, \mathrm{NO}_{3}^{-}, \mathrm{NO}_{2}{ }^{-}, \mathrm{CaCO}_{3}$,

Penilaian kualitas airtanah terbagi menjadi dua, yaitu penilaian kualitas untuk air minum dan penilaian kualitas untuk air irigasi. Penilaian airtanah untuk air minum didasarkan pada PERMENKES No.492/MENKES/PER/IV/2010 dan WHO 2011. Penilaian kualitas airtanah untuk air irigasi berdasarkan perhitungan nilai SAR (Sodium Absorption Ratio) denganklasifikasi Richard (1954) dan nilai salinity hazard (EC) dengan klasifikasi Wilcox (1955).

Wijaya (2016) telah melakukan penilaian kalitas aitanah menggunakan metode WQI yang berlokasi di Kabupaten Klaten. Dalam penelitian tersebut parameter yang digunakan hanya berjumlah 6 parameter baik untuk WQI dengan standar PERMENKES 2010 maupun WQI dengan standar WHO 2011. Keenam parameter tersebut yaitu: $\mathrm{pH}, \mathrm{TDS}, \mathrm{SO}_{4}{ }^{2-}, \mathrm{Cl}^{-}, \mathrm{NO}_{3}^{-}$, dan kesadahan.

Dalam penelitian ini, parameter yang digunakan dibagi menjadi 2 kelompok, yaitu parameter fisik dan parameter kimia. Menurut Apello dan Postma (2005), parameter fisik yang dapat digunakan untuk uji kualitas airtanah minimal harus terdapat unsur konduktivitas (EC) dan parameter kimia didasarkan pada kandungan anion utama $\left(\mathrm{Cl}^{-}, \mathrm{HCO}_{3}{ }^{-}, \mathrm{SO}_{4}{ }^{2}\right.$, dan $\left.\mathrm{NO}_{3}{ }^{-}\right)$dan kation utama $\left(\mathrm{Ca}^{2+}, \mathrm{Mg}^{2+}, \mathrm{Na}^{+}\right.$, dan $\left.\mathrm{K}^{+}\right)$dalam airtanah.

Senyawa Nitrogen ada di air dalam bentuk Nitrat $\left(\mathrm{NO}_{3}{ }^{-}\right)$dan Nitrit $\left(\mathrm{NO}_{2}^{-}\right)$memiliki peran 
yang sangat penting. Kandungan Nitrat $\left(\mathrm{NO}_{3}{ }^{-}\right)$ yaitu sebagai indikator terjadinya pencemaran yang diakibatkan limbah domestik dan limbah industri (Darmanto, 2014) serta menunjukkan adanya aktivitas pertanian (Effendi, 2003; Sudarmadji, 2013). Pencemaran airtanah oleh nitrat merupakan masalah yang paling banyak didunia (Gu dkk., 2013; Adimalla, 2020). Potensi terjadinya kontaminasi nitrat dalam airtanah dapat terjadi karena penggunaan pupuk anorganik, kebocoran septictank, limbah industri dan rumah tangga serta lindi dari tempat pembuangan akhir/sementara (TPA/TPS) (Wei dkk., 2017; Adimalla, 2020). Konsumsi air dengan kandungan Nitrat tinggi dapat menyebabkan Globinemia (bayi biru) pada bayi, penyakit lambung, cacat lahir, gangguan saraf hingga diabetes (Vasanthavigar dkk., 2010; Varol dan Davraz, 2015).

Selain kandungan Nitrat $\left(\mathrm{NO}_{3}^{-}\right)$dalam airanah saja, melainkan kandungan Nitrit $\left(\mathrm{NO}_{2}{ }^{-}\right)$ juga menjadi indikasi terjadinya pencemaran akibat dari imbah domestik dan pertanian (Prabowo dan Dewi, 2016). Lebih lanjut Prabowo dan Dewi (2016) menjelaskan bahwa pencemaran air sumur (airtanah) oleh bahan organik mengakibatkan kadar ammonia dan hidrogen sulfide dalam airtanah semakin meningkat. Amonia yang larut dalam air membentuk senyawa nitrit, dan dapat membentuk senyawa nirat. Nitrit sangat berbahaya untuk kesehatan, khususnya bayi dibawah umur 3 bulan. Nitrit dapat menyebabkan methamoglinemia.

Sener dkk. (2017) mengevaluasi kualitas air dengan menggunakan parameter Nitrit $\left(\mathrm{NO}_{2}{ }^{-}\right)$. Nitrit lebih beracun bagi hewan dan kesehatan manusa daripada Nitrat $\left(\mathrm{NO}_{3}^{-}\right)$(Varol dan Davraz, 2015).

Parameter yang digunakan untuk setiap standardisasi berbeda. WQI dengan standar PERMENKES 2010 menggunakan 6 parameter yaitu; $\mathrm{pH}, \mathrm{TDS}, \mathrm{SO}_{4}{ }^{2-}, \mathrm{Cl}^{-}, \mathrm{NO}_{3}{ }^{-}$, dan kesadahan (Wijaya, 2016). Sedangkan WQI dengan standar WHO menggunakan 13 parameter, yaitu $\mathrm{pH}$, EC, TDS, $\mathrm{Ca}^{2+}, \mathrm{Mg}^{2+}, \mathrm{Na}^{+}, \mathrm{K}^{+}, \mathrm{Cl}^{-}, \mathrm{HCO}_{3}{ }^{-}, \mathrm{SO}_{4}{ }^{2}$, $\mathrm{NO}_{3}^{-}, \mathrm{NO}_{2}^{-}$, dan kesadahan.

Penilaian dilakukan dengan pembobotan WQI dari parameter sifat fisik dan kimia yang terkandung dalam sampel airtanah. Masingmasing parameter diberi bobot sesuai dengan pengaruhnya terhadap kesehatan. Klasifikasi
Tabel 1. Klasifikasi kualitas airtanah untuk air minum berdasarkan nilai WQI (Sahu dan Sikdar, 2008)

\begin{tabular}{lc}
\hline \multicolumn{1}{c}{ Rentang Nilai } & Kualits Air \\
\hline$<50$ & Sangat Baik \\
$50-100$ & Baik \\
$100-200$ & Buruk \\
$200-300$ & Sangat Buruk \\
$>300$ & Tidak Layak \\
\hline
\end{tabular}

kualitas airtanah untuk air minum dengan menggunakan WQI terbagi menjadi 5 kelas (Tabel 1).

Penentuan nilai WQI menggunakan Persamaan [1] (Brown dkk., 1972; RamyaPriya dan Elango, 2018).

$W Q I=\sum S I$

Dimana nilai SI (subindex) diperoleh dari persamaan [2] (Brown dkk., 1972; RamyaPriya dan Elango, 2018).

$S I=W i \times q i$

Nilai Wi didapatkan dari persamaan [3]

$W i=\frac{w i}{\sum_{i=1}^{n} w i}$

Dimana nilai wi merupakan bobot relatif yang diberikan pada masing-masing parameter dan $\mathrm{n}$ adalah jumlah parameter.

Quality rating scale (qi) didapatkan dari perbandingan nilai parameter ( $c i)$ terhadap nilai standar yang ditetapkan (si) dikalikan 100, sehingga nilai qi diperoleh persamaan [4] (Brown dkk., 1972; RamyaPriya dan Elango, 2018).

$q i=\frac{C i}{S i} \times 100$

Kualitas airtanah untuk air irigasi, penilaian menggunakan perhitungan nilai SAR (Sodium Absorption Ratio), Presentase Sodium (Na\%), dan RSC (Residual Sodium Carbonate). Klasifikasi SAR berdasarkan Richard (1954), klasifikasi Na\%berdasarkan Wilcox (1955) dan klasifikasi RSC berdasarkan Raghunath (1987).

Nilai SAR dapat diperoleh dengan persamaan [5] (Li dkk., 2018). Klasifikasi kualitas airtanah untuk irigasi berdasarkan nilai SAR dapat dilihat pada Tabel 2.

$\mathrm{SAR}=\mathrm{Na}^{+} /\left\{\sqrt{ }\left(\mathrm{Ca}^{2+}+\mathrm{Mg}^{2+}\right) / 2\right\}$ 
Tabel 2. Klasifikasi kualitas airtanah untuk air irigasi berdasarkan nilai SAR dalam mg/L (Richard, 1954),

\begin{tabular}{lc}
\hline \multicolumn{1}{c}{ Rentang Nilai } & Kualits Air \\
\hline $0-10$ & Sangat baik \\
$10-18$ & Baik \\
$18-26$ & Meragukan \\
$>26$ & Tidak Cocok \\
\hline
\end{tabular}

Tabel 3. Klasifikasi kualitas airtanah untuk air irigasi berdasarkan nilai Na\% dalam meq/L (Wilcox, 1955)

\begin{tabular}{lc}
\hline \multicolumn{1}{c}{ Rentang Nilai } & Kualits Air \\
\hline$<20$ & Sangat baik \\
$20-40$ & Baik \\
$40-60$ & Dibolehkan \\
$60-80$ & Meragukan \\
$>80$ & Tidak Cocok \\
\hline
\end{tabular}

Tabel 4. Klasifikasi kualitas airtanah untuk air irigasi berdasarkan RSC dalam meq/L (Raghunath, 1987)

\begin{tabular}{lc}
\multicolumn{1}{c}{ Rentang Nilai } & Kualits Air \\
\hline$<1,25$ & Baik \\
$1,25-2,5$ & Meragukan \\
$>2,5$ & Tidak Cocok \\
\hline
\end{tabular}

Nilai persentase Sodium $(\mathrm{Na} \%)$ dapat diperoleh dengan persamaan [6] (Wu dan Sun, 2016). Klasifikasi kualitas airtanah untuk irigasi berdasarkan nilai $\mathrm{Na} \%$ dapat dilihat pada Tabel 3.

$\mathrm{Na} \%=\frac{\left(\mathrm{Na}^{+}+\mathrm{K}^{+}\right) \times 100}{\mathrm{Ca}^{2+}+\mathrm{Mg}^{2+}+\mathrm{Na}^{+}+\mathrm{K}^{+}}$

Nilai RSC dapat diperoleh dengan persamaan [7] (Wu dan Sun, 2016). Klasifikasi kualitas airtanah untuk irigasi berdasarkan nilai RSC dapat dilihat pada Tabel 4.

$\mathrm{RSC}=\left(\mathrm{HCO}_{3}^{-}+\mathrm{CO}_{3}^{-}\right)-\left(\mathrm{Ca}^{2+}+\mathrm{Mg}^{2+}\right)$ [7]

Analisis data spasial menggunakan surfer 11.0 dan ArcGis 10.3.1 untuk menggambarkan distribusi nilai dari $\mathrm{pH}, \mathrm{EC}$, TDS, kesadahan dan kondisi muka airtanah.

\section{HASIL}

Hasil penelitian terbagi menjadi 2 topik, yaitu peruntukan airtanah sebagai air minum dan peruntukan airtanah sebagai air irigasi. Hasil pngujian tiap sampel dan tiap parameter dinilai sesuai dengan standart menurut PERMENKES 2010 dan WHO 2011. Nilai minimal, maksimal, rata-rata, nilai standar menurut PERMENKES 2010 dan WHO 2011, bobot dan bobot ralatif dari tiap parameter disajikan pada Tabel 5 .

Tabel 5 menunjukan parameter yang digunakan dalam penentuan WQI menggunakan 10 sampel airtanah terpilih berdasarkan kondisi geologi dan tataguna lahan sekitar titik sampel. Penentuan WQI berdasarkan PERMENKES 2010 menggunakan 6 parameter, sedangkan penentuan WQI berdasarkan WHO 2011 menggunakan 13 parameter. Nilai $\mathrm{pH}$ memiliki rentang 5,1-6,7 dengan rata-rata 6,03. Nilai EC memiliki rentang 51,3-5.920 $\mu \mathrm{S} / \mathrm{cm}$ dengan ratarata $2.022 \mu \mathrm{S} / \mathrm{cm}$. Konsentrasi TDS berkisar antara 36-4.000 mg/L dengan rata-rata $1.354,8$ $\mathrm{mg} / \mathrm{L}$.

Tabel 5. Data statistik, bobot, dan bobot relatif untuk menentukan kualitas airtanah

\begin{tabular}{|c|c|c|c|c|c|c|c|c|}
\hline Parameter & Min & Maks & $\begin{array}{l}\text { Rata- } \\
\text { rata }\end{array}$ & $\begin{array}{l}\text { Bobot } \\
(w i)^{1}\end{array}$ & $\begin{array}{c}\text { PERMENKES } \\
(\mathbf{2 0 1 0})\end{array}$ & $\begin{array}{c}\text { Bobot } \\
\text { Relatif } \\
(\mathrm{W} i)^{2}\end{array}$ & $\begin{array}{l}\text { WHO } \\
(2011)\end{array}$ & $\begin{array}{c}\text { Bobot } \\
\text { Relatif } \\
(\mathbf{W i})^{3}\end{array}$ \\
\hline $\mathrm{pH}$ & 5,1 & 6,7 & 6,03 & 4 & $6,5-8,5$ & 0,18 & $6,5-8,5$ & 0,1 \\
\hline $\mathrm{EC}$ & 51,3 & 5.920 & 2.022 & 4 & - & - & 1.000 & 0,1 \\
\hline TDS & 36 & 4.000 & $1.354,8$ & 5 & 500 & 0,23 & 1.000 & 0,12 \\
\hline $\mathrm{Ca}^{2+}$ & 3,45 & 101,02 & 38,167 & 2 & - & - & 75 & 0,047 \\
\hline $\mathrm{Mg}^{2+}$ & 1,33 & 490,24 & 72,1 & 2 & - & - & 50 & 0,047 \\
\hline $\mathrm{Na}^{+}$ & 7,62 & 338,51 & 89,29 & 3 & - & - & 200 & 0,07 \\
\hline $\mathrm{K}^{+}$ & 0 & 43,03 & 12,52 & 1 & - & - & 12 & 0,02 \\
\hline $\mathrm{SO}_{4}{ }^{2-}$ & 0,9 & 400,1 & 88,32 & 3 & 250 & 0,13 & 250 & 0,07 \\
\hline $\mathrm{Cl}^{-}$ & 7,7 & $1.809,4$ & 310,43 & 3 & 250 & 0,13 & 250 & 0,07 \\
\hline $\mathrm{NO}_{3}^{-}$ & 0 & 29,1 & 7,44 & 5 & 50 & 0,23 & 50 & 0,12 \\
\hline $\mathrm{NO}_{2}^{-}$ & 0 & 7,4 & 1,25 & 5 & - & - & 3 & 0,12 \\
\hline $\mathrm{HCO}_{3}^{-}$ & 26,76 & 307,76 & 142,95 & 3 & - & - & 120 & 0,07 \\
\hline Kesadahan & 14,2 & $2.296,6$ & 396,01 & 2 & 500 & $\begin{array}{r}0,1 \\
\Sigma \mathrm{W} i=1\end{array}$ & 500 & $\begin{array}{r}0,047 \\
\Sigma W i=1 \\
\end{array}$ \\
\hline
\end{tabular}

\footnotetext{
${ }^{1}$ Wijaya (2016); Sener dkk. (2017); Kawo dkk. (2018)

${ }^{2}$ Bobot relatif untuk WQI berdasarkan PERMENKES 2010

${ }^{3}$ Bobot retalif untuk WQI berdasarkan WHO 2011
} 
Kation $\mathrm{Na}^{+}$merupakan kation dominan yang terdapat dalam sampel lokasi penelitian sedangkan untuk anion, parameter $\mathrm{HCO}_{3}{ }^{-}$yang dominan daripada parameter anion lainnya. Konsenrasi minimum $\mathrm{Na}^{+}$sebesar 7,62 $\mathrm{mg} / \mathrm{L}$ sedangkan nilai maksimumnya $338,51 \mathrm{mg} / \mathrm{L}$. Rata-rata konsentrasi $\mathrm{Na}^{+}$dalam sampel airtanah lokasi penelitian adalah 89,29 mg/L. Konsentrasi $\mathrm{HCO}_{3}{ }^{-}$dalam lokasi penelitian berkisar antara 26,76-307,76 mg/L, dengan rata-rata 142,95 $\mathrm{mg} / \mathrm{L}$.

Konsenrasi kation lain seperti $\mathrm{Ca}^{2+}$ berkisar antara 3,45-101,02 $\mathrm{mg} / \mathrm{L}$, dengan rata-rata $38,167 \mathrm{mg} / \mathrm{L}$. Rentang konsentrasi $\mathrm{Mg}^{2+}$ antara 1,33-490,24 mg/L dengan rata-rata 72,1 mg/L. Konsentrasi $\mathrm{K}^{+}$berkisar antara $0-43,03 \mathrm{mg} / \mathrm{L}$ dengan rata-rata $12,52 \mathrm{mg} / \mathrm{L}$.

Konsentrasi anion lainya seperti $\mathrm{SO}_{4}{ }^{2-}$ berkisar antara 0,9-400,1 mg/L dengan rata-rata $88,32 \mathrm{mg} / \mathrm{L}$. konsentrasi $\mathrm{Cl}^{-}$berkisar antara 7,7$1.809,4 \mathrm{mg} / \mathrm{L}$ dengan rata-rata $310,43 \mathrm{mg} / \mathrm{L}$.

Konsentrasi Nitrat $\left(\mathrm{NO}_{3}{ }^{-}\right)$berkisar antara 0$29,1 \mathrm{mg} / \mathrm{L}$ dengan rata-rata $7,44 \mathrm{mg} / \mathrm{L}$. Konsentrasi Nitrit $\left(\mathrm{NO}_{2}^{-}\right)$berkisar antara 0-7,4 $\mathrm{mg} / \mathrm{L}$ dengan rata-rata $1,25 \mathrm{mg} / \mathrm{L}$. Rentang nilai kesadahan antara 14,2 - 2.296,6 mg/L dengan rata-rata $396,01 \mathrm{mg} / \mathrm{L}$.

Masing-masing parameter diberi bobot dari skala 1 (pengaruhnya paling kecil terhadap kualitas air) sampai 5 (pengaruhnya palng besar terhadap kualitas air). Bobot 1 diberikan pada parameter $\mathrm{K}^{+}$. Bobot 2 diberikan pada parameter $\mathrm{Ca}^{2+}, \mathrm{Mg}^{2+}$, dan kesadahan. Bobot 3 diberikan pada parameter $\mathrm{Na}^{+}, \mathrm{SO}_{4}{ }^{2-}, \mathrm{Cl}^{-}$, dan $\mathrm{HCO}_{3}{ }^{-}$. Bobot 4 diberikan pada parameter $\mathrm{pH}$ dan EC. Sedangkan bobot tertinggi dengan skala 5 diberikan pada parameter TDS, Nitrat $\left(\mathrm{NO}_{3}{ }^{-}\right)$ dan Nitrit $\left(\mathrm{NO}_{2}^{-}\right)$.

\section{PEMBAHASAN}

Secara umum, sifat kimia dalam airtanah dapat menggambarkan kondisi airtanah tersebut. Akitivitas manusia dan kondisi geologi regional merupakan dua faktor terpenting yang mempengaruhi hidrologeologi dan kualitas airtanah (Yang dkk., 2012).

\section{Kondisi Hidrogeologi}

Kondisi hidrogeologi lokasi penelitian diketahui dari titik survei minatan yang tersebar. Titik survei minatan berupa sumur

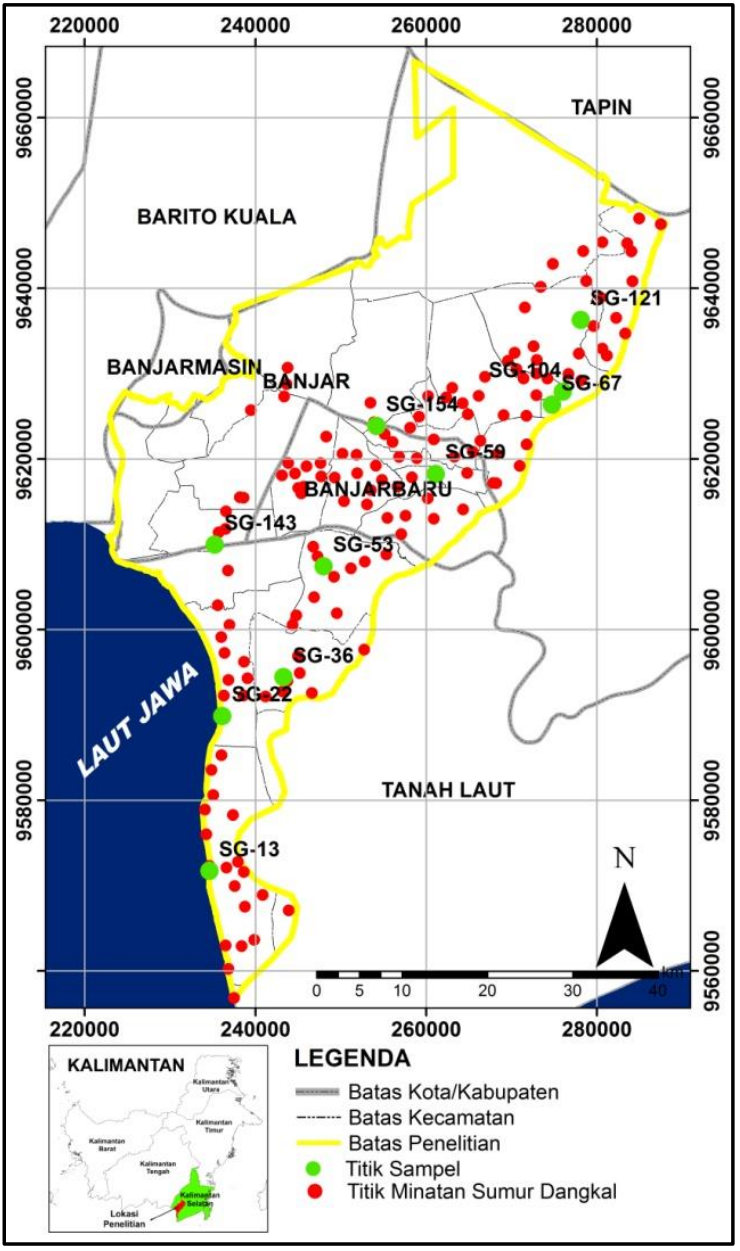

Gambar 4. Peta lokasi titik minatan dan titik sampel penelitian

dangkal yang merepresentasikan sebagai akuifer tidak tertekan. Berdasarkan hasil pemetaan dilapangan didapatkan 150 titik minatan airtanah dan 10 sampel hidrokimia airtanah (Gambar 4).

Analisis muka airtanah ditentukan dari 150 titik minatan yang tersebar di lokasi penelitian. Nilai muka airtanah lokasi penelitian antara 0,09-43,57 mdpl. Arah aliran airtanah dari bagian timur ke barat lokasi penelitian (Gambar 5). Jika dilihat dari topografi lokasi penelitian, dimana bagian timur memiliki topografi yang lebih tinggi jika dibandingkan bagian barat. Maka arah aliran airtanah mengikuti topografi.

Berdasarkan 10 sampel yang dilakukan pengukuran derajat keasaman $(\mathrm{pH})$ hasilnya berkisar antara 3,37- 7,58 dengan rata-rata 5,68. Hasil tersebut menunjukkan nilai $\mathrm{pH}$ terendah terdapat pada SG-45 di Landasan Ulin, Lianganggang dengan nilai $\mathrm{pH}$ sebesar 


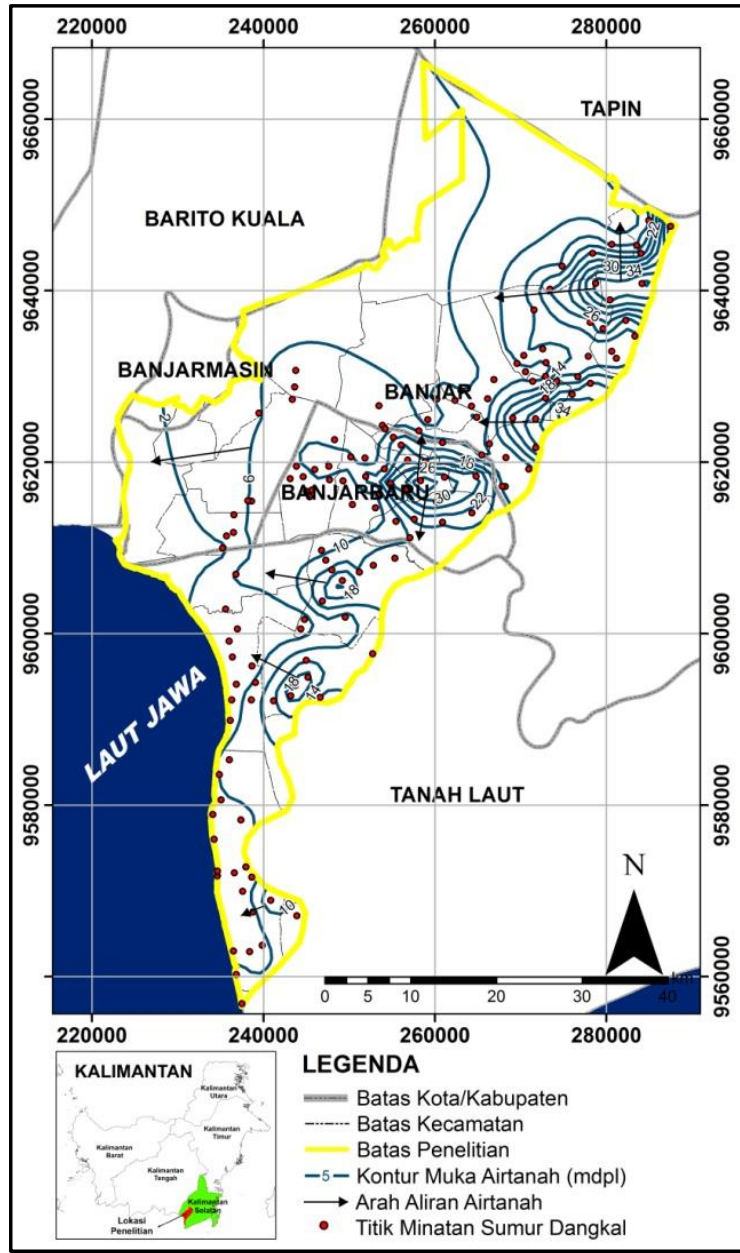

Gambar 5. Peta muka airtanah dan arah aliran airtanah lokasi penelitian

3,37 dan nilai $\mathrm{pH}$ tertinggi diketahui pada SG-44 di Pembataan, Lianganggang dengan nilai $\mathrm{pH}$ sebesar 7,58.

Gambar 6 menunjukkan peta spasial interpolasi dari hasil pengujian $\mathrm{pH}$ di lokasi penelitian. Airtanah di lokasi penelitian memiliki sifat asam hingga basa. Nilai $\mathrm{pH}$ yang rendah dapat terjadi kerana interasi antara airtanah dan batuan sekitar. Nilai $\mathrm{pH}$ yang tinggi menunjukkan waktu pengisian airtanah yang lambat (Mahamat dkk., 2017).

Nilai konduktivitas (EC) lokasi penelelitian berkiasar antara 5,95-5.970 $\mu \mathrm{S} / \mathrm{cm}$. Peta spasial nilai EC (Gambar 7) menggambarkan bahwa nilai EC airtanah pada lokasi penelitian rendah pada bagian timur, dimana bagian timur merupakan daerah dengan elevasi tinggi. Daerah dengan nilai konduktivitas yang rendah dan elevasi yang tinggi dapat menjadi daerah imbuhan dari suatu sistem airtanah (Kawo dkk., 2018).

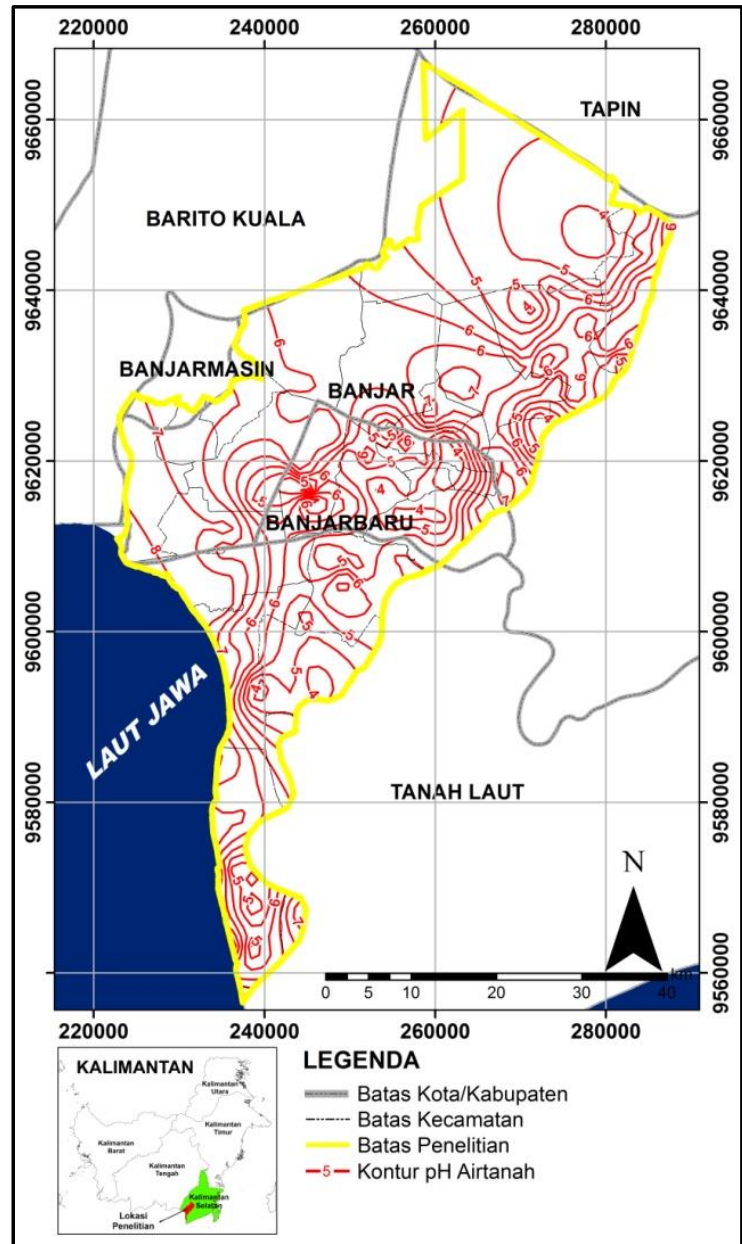

Gambar 6. Peta derajat keasaman $(\mathrm{pH})$ airtanah lokasi penelitian

Semakin ke arah barat dari lokasi penelitian, nilai EC semakin tinggi. Hal ini disebabkan karena di bagian barat lokasi penelitian berbatasan langsung dengan Laut Jawa. Faktor muka airtanah yang semakin rendah dibagian barat lokasi penelitian juga mempengaruhi nilai EC di daerah tersebut. Semakin dekat muka airtanah dengan permukaan tanah, maka kontaminasi antara airtanah dan air laut semakin besar, khususnya airtanah yang jaraknya dekat dengan air laut.

Menurut Subba Rao dkk (2012), EC dapat diklasifikasikan sebagai tipe I (pengayaan garam rendah) dengan nilai EC $<1.500 \mu \mathrm{S} / \mathrm{cm}$; tipe II (pengayaan garam sedang) dengan nilai EC $1.500-3.000 \mu \mathrm{S} / \mathrm{cm}$; dan tipe III (pengayaan garam tinggi) dengan nilai $\mathrm{EC}>3.000 \mu \mathrm{S} / \mathrm{cm}$. Sampel airtanah lokasi penelitian termasuk kedalam tipe III sebanyak 4 sampel atau sebesar $40 \%$ dan sebanyak 6 sampel atau sebesar $60 \%$ termasuk kedalam tipe I. 


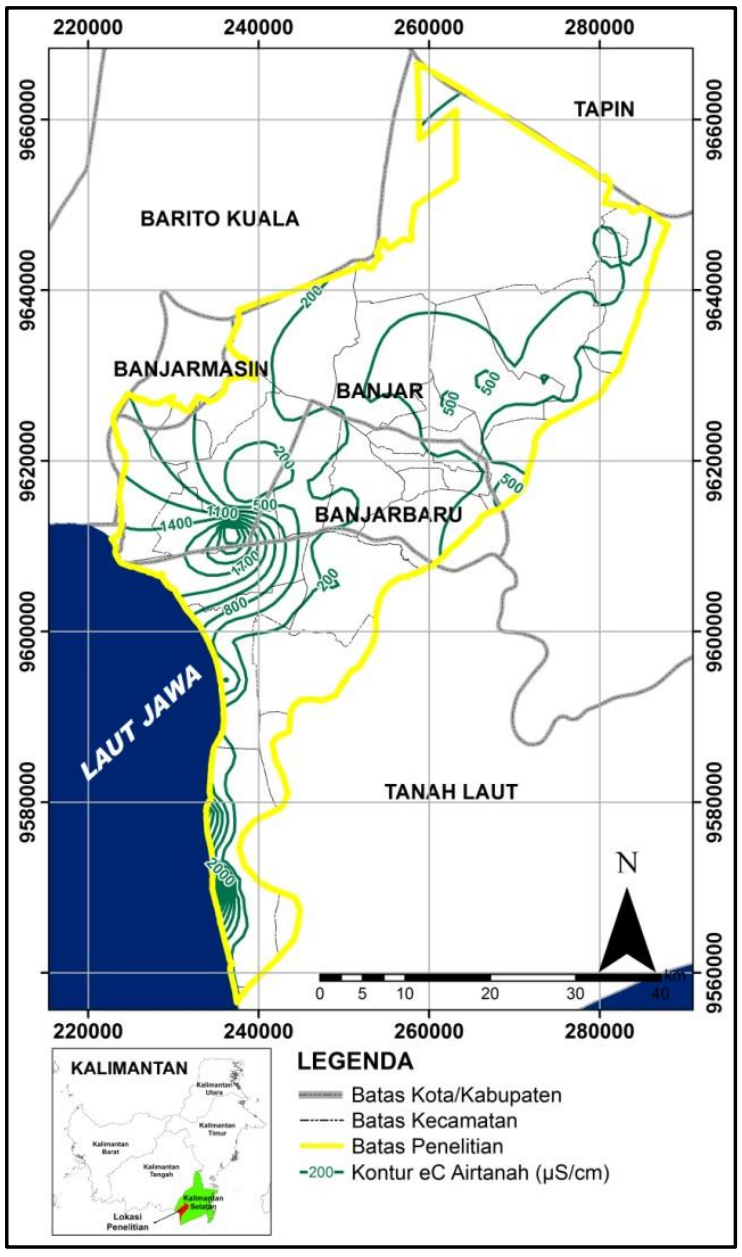

Gambar 7. Peta konduktivitas (EC) airtanah lokasi penelitian

Persebaran nilai TDS (Jumlah Zat Terlarut) lokasi penelitian ditunjukkan pada peta spasial nilai TDS (Gambar 8). Hasil analisis menunjukan bahwa nilai TDS lokasi penelitian antara 36-4.000 mg/L. Gambar 8 menunjukkan dimana semakin ke arah utara, nilai TDS semakin tinggi.

Davis dan DeWiest (1966) mengelompokkan TDS menjadi 4, yaitu TDS $<500 \mathrm{mg} / \mathrm{L}$ (diperlukan untuk diminum); TDS $500-1.000$ $\mathrm{mg} / \mathrm{L}$ (diizinkan untuk diminum); TDS 1.000 $3.000 \mathrm{mg} / \mathrm{L}$ (digunakan untuk irigasi); TDS > $3.000 \mathrm{mg} / \mathrm{L}$ (tidak layak untuk minum dan irigasi). Berdasarkan klasifikasi tersebut, sampel lokasi penelitian termasuk kedalam 3 kelompok, yaitu sebanyak 6 sampel (60\%) diperlukan untuk air minum, 2 sampel (20\%) digunakan untuk irigasi, dan 2 sampel (20\%) tidak layak minum dan irigasi.

Kesadahan airtanah dipengaruhi oleh kandungan senyawa kalsium dan magnesium serta berbagai logam lainnya (Duraisany dkk.,

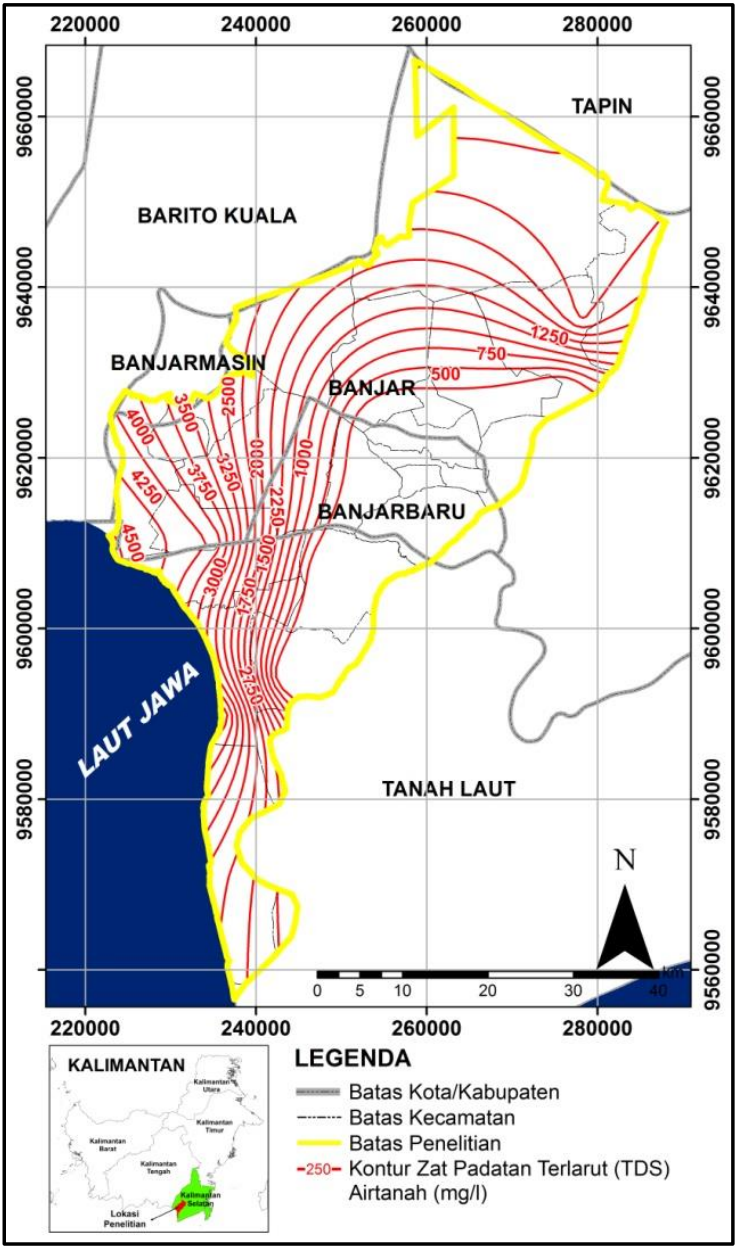

Gambar 8. Peta jumlah zat terlarut (TDS) airtanah lokasi penelitian

2018; Alaya dkk., 2014). Konsentrasi kesadahan yang lebih tinggi dari $300 \mathrm{mg} / \mathrm{L}$ dapat menyebabkan masalah kesehatan, seperti pembentukan batu ginjal (Jain dkk., 2010).

Persebaran nilai kesadahan lokasi penelitian ditunjukkan pada peta spasial nilai kesadahan (Gambar 9). Hasil analisis menunjukan bahwa nilai kesadahan lokasi penelitian antara 14-2.296 $\mathrm{mg} / \mathrm{L}$. Gambar 9 menunjukkan bahwa nilai kesadahan semakin tinggi ke arah barat.

Sawyer dan McCarthy mengklasifikasikan tingkat kesadahan menjadi 4 kelompok, yaitu: air lunak (< $75 \mathrm{mg} / \mathrm{L})$, kesadahan sedang (75-150 mg/L), sadah (150$300 \mathrm{mg} / \mathrm{L}$ ), dan kesadahan tinggi (>300 mg/L). Berdasarkan klasifikasi tersebut, sampel dari lokasi penelitian termasuk kedalam air lunak (6 sampel), air sadah (1 sampel), dan air dengan kesadahan tinggi (3 sampel). 


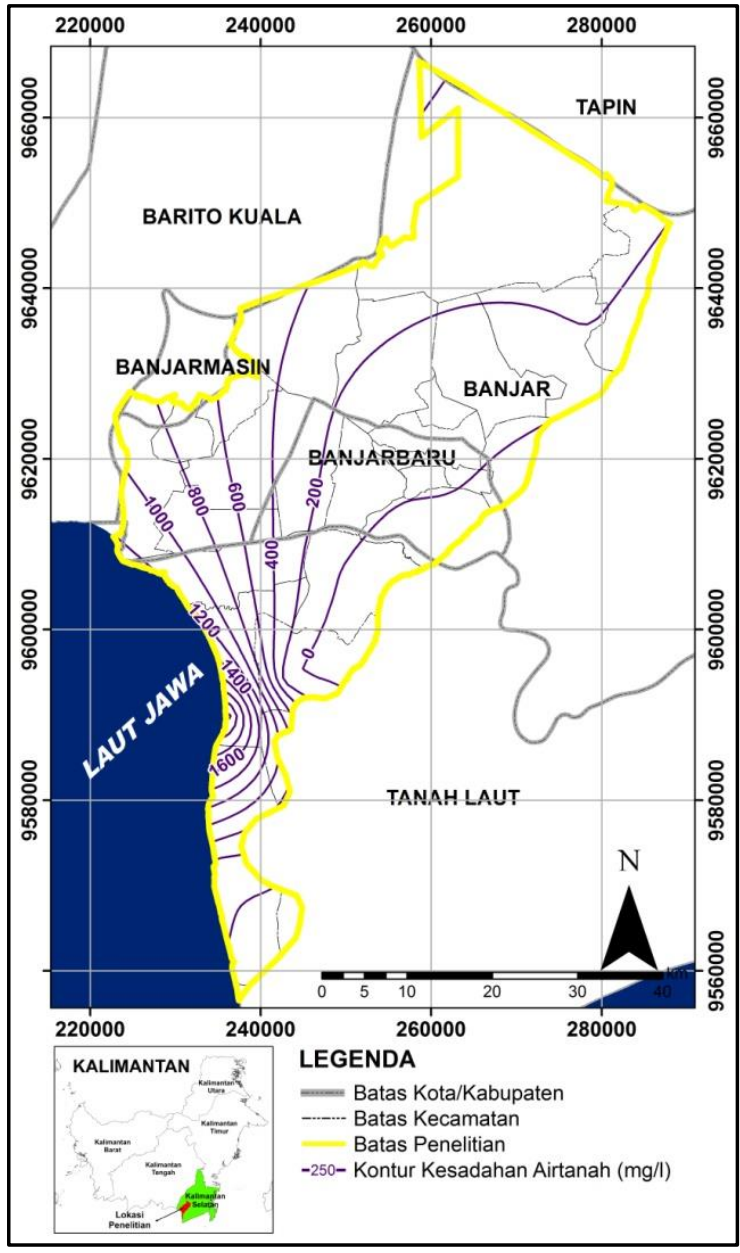

Gambar 9. Peta kesadahan airtanah lokasi penelitian

\section{Penilaian untuk Air Minum}

Parameter yang digunakan dalam penentuan kualitas airtanah menggunakan metode WQI ditunjukkan pada Tabel 5. Hasil perhitungan nilai WQI menurut klasifikasi PERMENKES (2010) didapatkan sekitar 20,31-351,14. Berdasarkan klasifikasi kualitas airtanah (Tabel 1), sampel airtanah di lokasi penelitian terbagi menjadi 4 kelompok, yaitu: kualitas air sangat baik untuk air minum, kualitas buruk untuk air minum, kualitas sangta buruk untuk air minum dan kualitas tidak layak minum.

Hasil perhitungan nilai WQI menurut klasifikasi WHO (2011) didapatkan sekitar 13,81-305,37. Berdasarkan klasifikasi kualitas airtanah (Tabel 1), sampel airtanah di lokasi penelitian juga terbagi menjadi 4 kelompok yaitu: kualitas air sangat baik untuk air minum, kualitas buruk untuk air minum, kualitas sangat buruk untuk air minum dan kualitas tidak layak minum. Klasifikasi kualitas airtanah lokasi penelitian tersaji dalam Tabel 6 .
Tabel 6. Klasifikasi kualitas airtanah lokasi penelitian berdasarkan PERMENKES (2010) dan WHO (2011)

\begin{tabular}{lccc}
\hline $\begin{array}{c}\text { Rentang } \\
\text { Nilai }\end{array}$ & $\begin{array}{c}\text { Kualits } \\
\text { Air }\end{array}$ & $\begin{array}{c}\text { Jumlah } \\
\text { Sampel }\end{array}$ & $\begin{array}{c}\text { Presentase } \\
(\boldsymbol{\%})\end{array}$ \\
\hline$<50$ & Sangat Baik & 6 & 60 \\
$50-100$ & Baik & - & - \\
$100-200$ & Buruk & 2 & 20 \\
$200-300$ & Sangat Buruk & 1 & 10 \\
$>300$ & Tidak Layak & 1 & 10 \\
\hline
\end{tabular}

Enam sampel airtanah memiliki kualitas air yang sangat baik yaitu SG-36, SG-53, SG-59, SG-67, SG-104 dan SG-154. Persebaran sampel airtanah dengan kualitas sangat baik umumnya berada di tengah lokasi penelitian. Dua sampel airtanah dengan kualitas buruk yaitu SG-13 dan SG-121. SG-13 berada di barat dari lokasi penelitian, sedangkan SG-121 berada di bagian timur lokasi penelitian. Satu sampel airtanah dengan kualitas sangat buruk dan satu sampel airtanah dengan kualitas tidak layak minum. Kedua sampel tersebut berada di bagian barat dari lokasi penelitian.

Dari 13 parameter yang digunakan untuk menentukan WQI berdasarkan WHO (2011), terdapat 10 parameter dari SG-13 yang tidak sesuai dengan batas yang diperbolehkan. Sedangkan menurut PERMENKES (2010), terdapat 4 dari 6 parameter yang tidak sesuai dengan ketentuan. Parameter yang tidak sesuai tersebut antara lain; $\mathrm{pH}, \mathrm{EC}$, TDS, $\mathrm{Ca}^{2+}, \mathrm{Mg}^{2+}$, $\mathrm{Na}^{+}, \mathrm{K}^{+}, \mathrm{SO}_{4}^{2-}, \mathrm{Cl}^{-}$, dan $\mathrm{HCO}^{3-}$ (Tabel 5). Sampel SG-121 memiliki 3 dari 13 parameter yang tidak sesuai dengan WHO (2011) dan 1 dari 6 parameter yang tidak sesuai dengan ketentuan PERMENKES (2010). Parameter yang tidak sesuai tersebut antara lain; EC, TDS, dan $\mathrm{HCO}^{3-}$ (Tabel 5).

Sampel dengan kode SG-143 merupakan sampel dengan kualitas sangat buruk. Terdapat 11 dari 13 parameter yang melebihi ketenuan berdasarkan WHO (2011), sedangkan menurut PERMENKES (2010) terdapat 4 dari 6 parameter yang tidak sesuai dengan ketentuan. Parameter yang tidak sesuai tersebut antara lain; EC, TDS, $\mathrm{Ca}^{2+}, \mathrm{Mg}^{2+}, \mathrm{Na}^{+}, \mathrm{K}^{+}, \mathrm{SO}_{4}{ }^{2-}, \mathrm{Cl}^{-}, \mathrm{HCO}^{3-}$ , dan Kesadahan (Tabel 5).

Sampel dengan kode SG-22 merupakan sampel dengan kualitas tidak layak minum. Terdapat 11 dari 13 parameter yang melebihi ketenuan berdasarkan WHO (2011), sedangkan 
Tabel 7. Parameter berdasarkan PERMENKES (2010) dan WHO (2011)

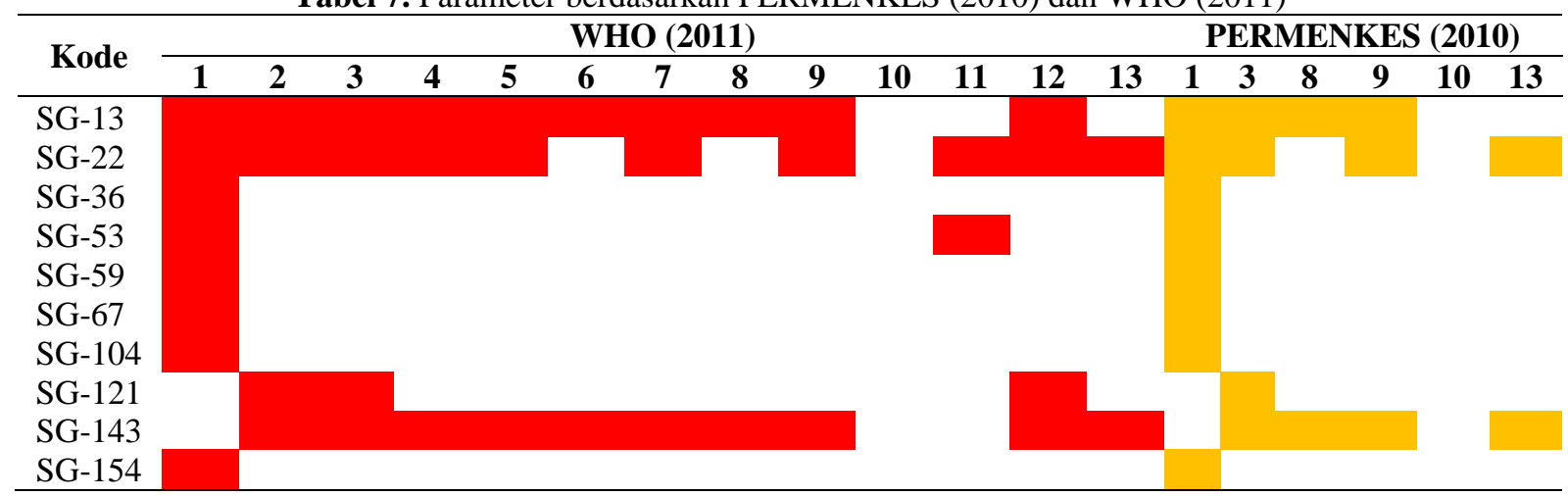

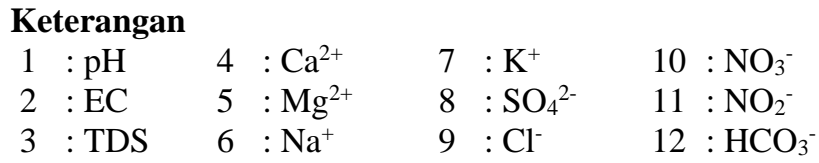

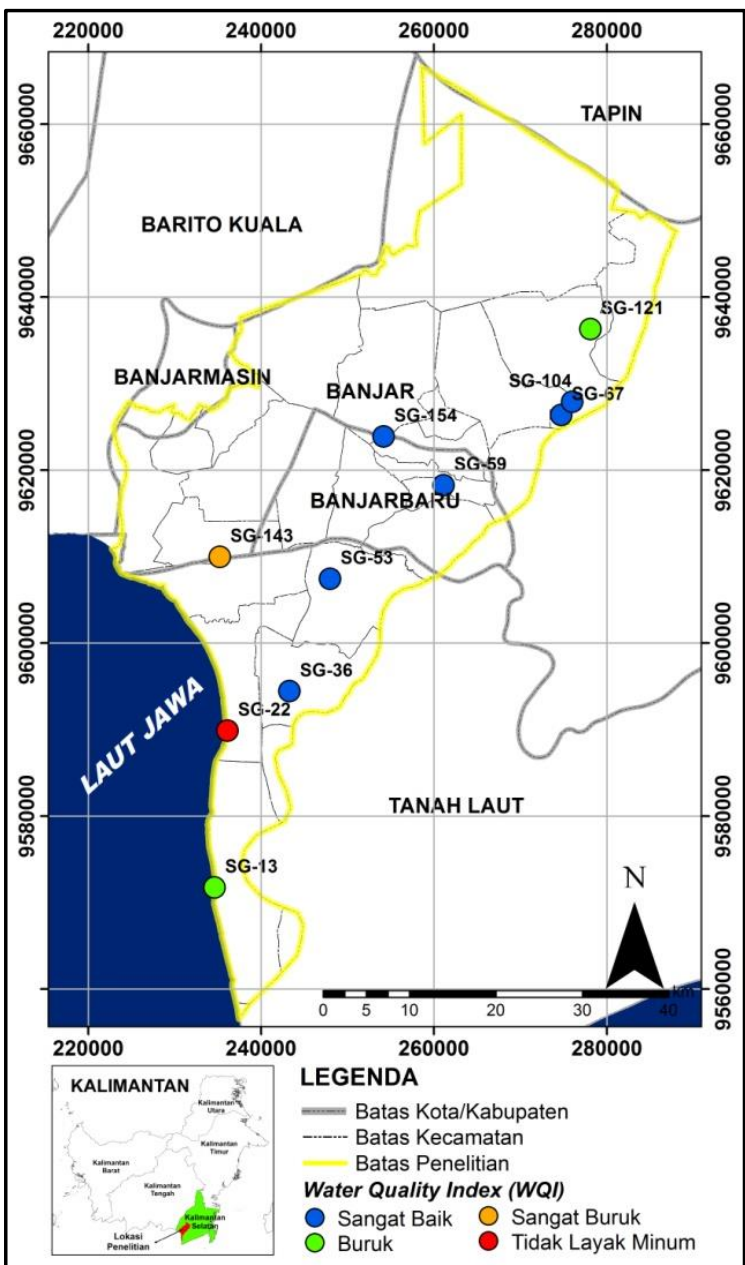

Gambar 10. Peta kualitas airtanah lokasi penelitian

menurut PERMENKES (2010) terdapat 3 dari 6 parameter yang tidak sesuai dengan ketentuan. Parameter yang tidak sesuai tersebut antara lain; $\mathrm{pH}, \mathrm{EC}, \mathrm{TDS}, \mathrm{Ca}^{2+}, \mathrm{Mg}^{2+}, \mathrm{Na}^{+}, \mathrm{K}^{+}, \mathrm{Cl}^{-}, \mathrm{HCO}^{3-}$, $\mathrm{NO}_{2}^{-}$, dan Kesadahan (Tabel 7).

\author{
13 : Kesadahan \\ Tidak sesuai dengan WHO (2011) \\ Tidak sesuai dengan PERMENKES (2010)
}

Parameter penting dengan bobot besar yang tidak sesuai dengan ketentuan menjadikan kualitas airtanah menurun karena jumlah perhitungannya lebih besar meskipun jumlah parameter yang tidak sesuai lebih sedikit. Beberapa parameter penting yang melebihi ketentuan pada sampel airtanah dengan kode SG-22 adalah Nitrit $\left(\mathrm{NO}_{2}^{-}\right)$dengan bobot 5 dan $\mathrm{pH}$ dengan bobot 4. Peta sebaran WQI dapat dilihat pada Gambar 10.

\section{Penilaian untuk Air Irigasi}

Ion terlarut dalam tanah secara berlebihan akan mempengaruhi kesuburan tanah. Kandungan garam dalam air dengan jumlah berlebih akan mengubah tekanan osmotic di zona akar(Bauder dan Brock, 2001; Hanson, dkk., 2006).Kadar garam dengan konsentrasi yang tinggi di tanah juga akan membatasi pertiumbuhan tanaman (Lie, dkk., 2011).

Penilaian kualitas air untuk keperluan irigasi menggunakan SAR berfungsi untuk mengukur kadar alkali/sodium. Menurut Kumar dkk. (2007), konsentrasi $\mathrm{Ca}$ dan $\mathrm{Mg}$ yang tinggi dalam air irigasi dapat mengurangi permeabilitas tanah. Nilai SAR pada sampel di lokasi penelitian antara $0,57-6,75 \mathrm{meq} / \mathrm{L}$ dengan nilai rata-rata $1,95 \mathrm{meq} / \mathrm{L}$. Semua sampel airtanah termasuk kedalam klasifikasi sangat baik (Tabel 8). Penentuan kualitas airtanah menggunakan Diagram Wilcox (Gambar 11a) berdasarkan nilai SAR dan EC. Hasilnya 6 sampel termasuk ke dalam kelompok C1-S1, dimana salinitas rendah dan kandungan sodium rendah, sehingga sangat cocok untuk air irigasi. Dua sampel termasuk ke 
dalam kelompok C4-S1, dimana salinitas sangat tinggi dan kandungan sodium rendah. Dua sampel termasuk ke dalam kelompok C4-S2, dimana salinitas sangat tinggi dan kandungan Sodium sedang. Air dengan salinitas yang sangat tinggi tidak cocok digunakan sebagai irigasi, hanya tanaman yang toleran terhadap garam yang mampu bertahan.

Penilaian kualitas airtanah untuk keperluan irigasi juga dapat menggunakan $\mathrm{Na} \%$ (Purushothman dkk., 2012). Hasil nilai $\mathrm{Na} \%$ berkisar antara 12,7-68,87\%, dengan rata-ata 41,97\%. Dari 10 sampel airtanah yang dianalisis, terdapat 2 sampel airtanah dengan kualitas sangat baik untuk keperluan air irigasi. Dua sampel dengan kualitas baik, 4 sampel dengan kualitas dibolehkan untuk air irigasi. Dua sampel dengan hasil meragukan untukkeperluan irigasi (Tabel 8). Diagram USSL (Gambar 11b) menunjukkan kulitas airtanah untuk keperluan irigasi berdasarkan $\mathrm{Na} \%$ dan $\mathrm{EC}$ dalam sampel airtanah. Hasilnya menunjukkan bahwa 6 sampel airtanah termasuk dalam kategori sangat baik untuk keperluan irigasi, dan 4 sampel lainnya tidak cocok digunakan untuk keperluan air irigasi.

Kesesuaian airtanah untuk air irigasi tergantung pada selisih antara jumlah kandungan Karbonat dan Bikarbonat dengan kandungan Kalsium dan Magnesium. Hasil penilaian kualitas airtanah dengan menggunakan RSC diperoleh nilai antara $-37,78-3,79 \mathrm{meq} / \mathrm{L}$ dengan rata-rata $-4,06 \mathrm{meq} / \mathrm{L}$. Nilai RSC menunjukkan bahwa 9 sampel airtanah di lokasi penelitian memiliki nilai $\mathrm{RSC}<1,25 \mathrm{meq} / \mathrm{L}$ sehingga baik digunakan sebagai air irigasi. Satu sampel airtanah memiliki nilai RSC $>2,5$ meq/L sehingga tidak cocok digunakan sebagai air irigasi (Tabel 8).

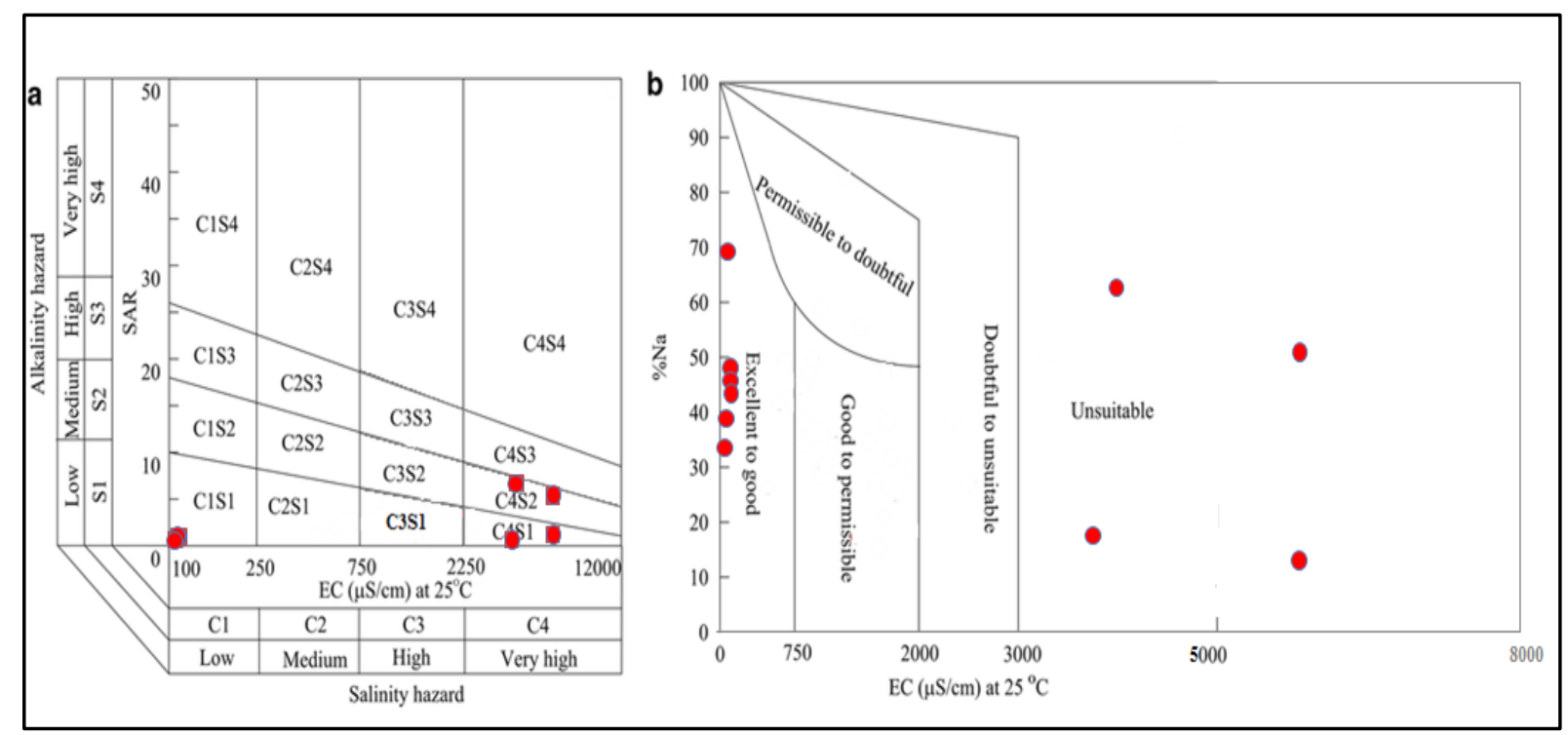

Gambar 11. Penilaian kualitas airtanah untuk irigasi lokasi penelitian. (a)Diagram Wilcox, (b)Diagram USSL

Tabel 8. Klasifikasi sampel airtanah untuk keperluan irigasi lokasi penelitian

\begin{tabular}{|c|c|c|c|c|c|c|}
\hline Klasifikasi & Min & Maks & Rata-rata & Rentang & Kualitas Air & Jumlah Sampe \\
\hline SAR (meq/L) & 0.57 & 6,75 & 1,95 & $<10$ & Sangat baik & 10 \\
\hline \multirow[t]{3}{*}{ (Richards, 1954) } & & & & $10-18$ & Baik & 0 \\
\hline & & & & $18-26$ & Meragukan & 0 \\
\hline & & & & $>26$ & Tidak Cocok & 0 \\
\hline & 12,7 & 68,87 & 41,97 & $<20$ & Sangat baik & 2 \\
\hline \multirow{4}{*}{ (Wilcox, 1955) } & & & & $20-40$ & Baik & 2 \\
\hline & & & & $40-60$ & Dibolehkan & 4 \\
\hline & & & & $60-80$ & Meragukan & 2 \\
\hline & & & & $>80$ & Tidak Cocok & 0 \\
\hline \multirow{3}{*}{$\begin{array}{c}\text { RSC (meq/L) } \\
\text { (Raghunath, 1987) }\end{array}$} & $-37,78$ & 3,79 & $-4,06$ & $<1,25$ & Baik & 9 \\
\hline & & & & $1,25-2,5$ & Meragukan & 0 \\
\hline & & & & 2,5 & Tidak Cocok & 1 \\
\hline
\end{tabular}




\section{KESIMPULAN}

Penilaian kualitas airtanah untuk air minum dil lokasi penelitian diperoleh kesimpulan bahwa sebanyak $60 \%$ memiliki kualitas yang baik serta layak konsumsi dan 40\% lainnya memiliki kualitas yang buruk sehingga tidak layak untuk dikonsumsi. Perlu diperhatikan bagaimana pemanfaatan airtanah dengan kualitas yang buruk agar tidak menimbulkan masalah kesehatan bagi masyarakat, baik dalam jangka pendek maupun jangka panjang. Sebagai alternatif untuk memenuhi kebutuhan air, masyarakat dapat memanfaatkan air minum dalam kemasan sebagai sumber air minum. Selain itu juga dapat memanfaatkan perusahaan penyedia air bersih untuk memenuhi kebutuhan air bersih.

Penilaian kualitas airtanah untuk keperluan irigasi diperoleh kesimpulan bahwa terdapat $80 \%$ airtanah yang dapat dimanfaatkan sebagai air irigasi, dan $20 \%$ sisanya tidak cocok digunakan sebagai air irigasi atau hanya dapat digunakan untuk tanaman-tanaman tertentu yang memiliki sifat tolerah terhadap kandungan garam yang tinggi. Meskipun begitu, kandungan garam yang tinggi dapat merusak kualitas tanah dan akan menurunkan hasil produksi pertanian.

\section{UCAPAN TERIMA KASIH}

Penulis mengucapkan terimakasih kepada Dinas Energi Sumber Daya Mineral Provinsi Kalimantan Selatan yang telah memfasilitasi kegiatan survei lapangan dan penyedia data sehingga penelitian dapat diselesaikan dengan baik.

\section{DAFTAR PUSTAKA}

Abdullah, Said., 2018. Air Sumur Tercemar, Warga Banjarbaru Diimbau Gunakan PDAM. Cendana News. https://www.cendananews.com/2018/02/air -sumur-tercemar-warga-banjarbarudiimbau-gunakan-pdam.html [diakses pada 3 Maret 2020].

Adimalla, N., 2020. Spatial Distribution, exposure, and potential health risk assessment from nitrate in drinking water from Semi-Arid Region of South India. Human and Ecological Risk Assessment, 26(2), hal.310-334. DOI: doi.org/10.1080/10807039.2018.1508329
Alaya, M.B., Saidi, S., Zemni, T. dan Zargouni, F., 2014. Suitability assessment of deepgroundwater for drinking and irrigation use in the Djeffara Aquifers (Northerngabes, South-Eastern Tunisia). Environmental Earth Sciences, 71(8), hal.3387-3421.

Baalousha, H. M., 2016. Groundwater vulnerability mapping of Qatar Aquifers. Journal of African Earth Sciences, 124, hal.75-93.

Badan Pusat Statistik (BPS) Kota Banjarbaru, 2015. Kota Banjarbaru Dalam Angka. Banjarbaru. Badan Pusat Statistik.

Badan Pusat Statistik (BPS) Kota Banjarbaru, 2018. Kota Banjarbaru Dalam Angka. Banjarbaru. Badan Pusat Statistik.

Bauder, J. dan Brock, T., 2001. Irrigation water quality, soil amendment, and crop effects on sodium leaching. Arid Land Research and Management, 15(2), hal.101113.

Brown, R.M., McCleiland, N.J., Deininger, R.A. dan O'Connor, M.F., 1972. A water quality index crossing the psychological barrier. Proceedings of the International Conference on Water Pollution Research, Jerusalem, 18-24 June 1972, hal.787-797.

Darmanto, D., 2014. Pencemaran Airtanah Studi Kasus Kawasan Sekitar Peternakan Ayam Wedomartani Sleman. Deepublish. Yogyakarta.

Davis, S.N. dan DeWiest, R.J., 1966. Hydrogeology. Wiley, Newyork.

Effendi, H., 2003.Telaah Kualitas Air, Bagi Pengelolaan Sumber Daya dan Lingkungan Perairan. Yogyakarta: Kanisius.

Gu, B., Ge, Y., Chang, S.X., Luo, W. dan Chang, J., 2013. Nitrate in groundwater of China:sources and driving forces. Global Environment. Change, 23(5), hal.11121121.

DOI: doi.org/10.1016/j.gloenvcha.2013.05.004

Hanson, B., Grattan, S. dan Fulton, A., 2006. Agricultural Salinity and Drainage. University of California Irrigation Programdivision of Agriculture and Natural Resources Publication 3375. University of California.

Heryanto, R. dan Sikumbang, N., 1994. Peta Geologi Regional Lembar Banjarmasin, Kalimantan, Skala 1:250.000. Pusat 
Penelitian dan Pengembangan Geologi. Bandung.

Hidayat, R.S., 2001, Peta Hidrogeologi Skala 1:250.000 Lembar Banjarmasin. Direktorat Tata Lingkungan Geologi dan Kawasan Pertambangan, Bandung.

Jahanshahi, R. dan Zare, M., 2016 Hydrochemical investigations for delineating salt-water intrusion into the Coastal Aquifer of Maharlou Lake, Iran Journal of African Earth Sciences, 121, hal.16-29.

DOI: doi.org/10.1016/j.jafrearsci.2016.05.014

Jain, C.K., Bandyopadhyay, A. dan Bhadra, A., 2010. Assessment of ground water quality for drinking purpose, District Nainital, Uttarakhand, India. Environmental Monitoring and Assessment, 166 hal.663676. DOI: doi.org/10.1007/s10661-0091031-5

Kawo, Nafyad Serre. dan Karuppannan, Shankar., 2018. Groundwater quality assessment using water quality index and gis technique in Modjo River Basin, Central Ethiopia. Jornal of African Earth Science, 147, hal.300-311. DOI: doi.org/10.1016/j.jafrearsci.2018.06.034

Kumar, M., Kumari, K., Ramanathan, A. dan Saxena, R., 2007. A comparative evaluation of groundwater suitability for irrigation and drinking purposes in two intensively cultivated districts of Punjab, India. DOI: doi.org/10.1007/s00254-007-0672-3

Environmental Geology, 53, hal.553-574.

Li, P., Wu, J., Tian, R., He, S., He, X., Xue, C. dan Zhang, K., 2018a. Geochemistry, Hydraulic Connectivity and Quality Appraisal of Multilayered Groundwater in the Hongdunzi Coal Mine, Northwest China. Mine Water and the Environment, 37(2), hal.222-237.

Mahamat, H.B., Coz, M.L., Abderamane, H., Sardini, P. dan Razack, M., 2017. Hydrochemicaland Isotopic Characteristics of the Basement Aquifer in the Wadi Fira Area, EasternChad. Journal of Water Resource and Protection, 9, hal.1688-1708.

Papaioannou, A., Plageras, P., Dovriki, E., Minas, A., Krikelis, V., Nastos, PTh., Kakavas, K. dan Paliatsos, AG., 2006. Groundwater quality and location of productive activities in the Region of
Thessaly (Greece). Desalination, 213, hal.209-217.

Peraturan Menteri Kesehatan RI No. 492/ MENKES/ PER/ IV/ 2010 Tentang Peryaratan Kualitas Air Minum.

Prabowo, R. dan Dewi, N.K., 2016. Kandungan nitrit pada air suur gali di Kelurahan Meteseh, Kecamatan Tembalang, Kota Semarang. Bioma, 5(1), hal.1-15.

Purushothman, P., Rao, M.S., Kumar, B., Rawat, Y.S., Krishan, G., Gupta, S., Marwah, S., Bhatia, A.K., Kaushik, Y.B., Angurala, M.P. dan Singh, G.P., 2012. Drinking and irrigation water quality in Jalandhar and Kapurthala Districts, Punjab, India: Using Hydrochemistry. International Journal of Earth Sciences and Engineering, 5(6), hal.1599-1608.

Putranto, T.T., Widiarso, D.A. dan Susanto, N., 2016. Assessment of groundwater quality to achieve sustainable development in Semarang Coastal Areas. IOP Conf. Series: Earth and Environmental Science, 79 (2017) 012001.

Raghunath, H.M., 1987. Ground Water: Hydrogeology, Ground Water Survey and Pumping Tests, Rural Water Supply and Irrigation Systems. New Age International (P) Ltd. Publishers ISBN-10: 0470206985.

RamyaPriya, R. dan Elango, L., 2018. Evaluation of geogenic and anthropogenic impacts on spatio-temporal variation in quality of surface water and groundwater alongCauvery River, India. Environmental Earth Science, 77 (1), hal.1-17.

Richard, L.A., 1954. Diagnosis and Improvement of Saline and Alkali Soils. US Department of Agriculture Handbook. Vol 60. Washington DC, USA.

Sadashivaiah C, Ramakrishnaiah $\mathrm{R}$ dan Ranganna, G., 2008. Hydrochemical analysis and evaluation of groundwater quality in Tumkur Taluk, Karnataka State, India. International Journal of Environmental Research and Public Health, 5(3), hal.158164.

Sahu, P. dan Sikdar, P.K., 2008. Hydrochemical framework of the aquifer in and around east kolkata wetlands, West Bengal, India. Environmental Geology, 55, hal.823-835. 
Sawyer, C. dan McCarthy, P., 1967. Chemical and Sanitary Engineering. second ed. McGraw-Hill, New York.

Sener, S., Sener, E. dan Davraz, A., 2017. Evaluation of water quality using water quality index (wqi) method and gis in Aksu River (SW-Turkey). Science of the Total Environment, 584-585, hal.131-144.

Sudarmadji, 2013. Mata Air. Yogyakarta: Sekolah Pascasarjana UGM.

Suharyadi, 1984. Geohidrologi. Universitas Gadjah Mada, Yogyakarta.

Varol, S. dan Davraz, A., 2015. Evaluation of the groundwater quality with WQI (WaterQuality Index) and multivariate analysis: a case study of the Tefenni Plain (Burdur/Turkey). Environmental Earth Science, 73, hal.1725-1744.

Vasanthavigar, M., Srinivasamoorthy, K., Vijayaragavan, K., Rajiv Ganthi, R., Chidambaram,S., Anandhan, P., Manivannan, R. dan Vasudevan, S., 2010. Application of water qualityindex for groundwater quality assessment: Thirumanimuttar Sub-Basin, Tamilnadu,India. Environmental Monitoring and Assessment, 171, hal.595609.

Wei, Y., Fan, W. dan Wang, W.,2017. Identification of Nitrate Pollution Sources ofGroundwater and Analysis of Potential Pollution Paths in Loess Regions: A Case Study in Tongchuan Region, China. Environmental Earth Science, 76, 423.

WHO (World Health Organization). 2011. Guideline for Drinking-Water Quality, Forth Edition. WHO Library Catalougingin-Publicating Data. ISBN 979924154815 1.

Wijaya, H., 2016. Analisis fasies hidrokimia dan interaksi aliran airtanah pada sistem akuifer dangkal di Perbukitan Jiwo Timur, Kecamatan Bayat, Kabupaten Klaten, Provinsi Jawa Tengah. Universitas Diponegoro; Semarang.

Wilcox, L.V., 1955. Classification and Use of Irrigation Water. United States Department of Agriculture.

Wu, J. dan Sun, Z., 2016. Evaluation of Shallow groundwater contamination and associated human health risk in an alluvial plain impacted by agricultural and industrial activities, Mid-West China. Expo Health, 8(3), hal.311-329.

Yang, L., Songl, X., Zhangl, Y., Hanl, D., Zhang, B. dan Long, D., 2012. Characterizing interactionsbetween surface water and groundwater in the Jialu River Basin using major ionchemistry and stable isotopes. Hydrology and Earth System Science, 16, hal.4265-4277. 